\title{
Action Environment Potential by the Private Higher Education within Tertiary LL Dikti III for the SN Dikti Implementation
}

\author{
Mohamad Sofyan ${ }^{\mathrm{a}} *$ \\ ${ }^{\alpha}$ Faculty of Administrative Science, Brawijaya University
}

\section{ARTICLE INFORMATION}

\section{Article history:}

Data submission : January 21, 2020

$1^{\text {st }}$ revision: May 20, 2020

Accepted: January 10, 2021

Available online: May 31, 2021

Keywords: potential capacity; action environment; private universities; adaptation; adoption.

\section{ABSTRACT}

Today, private universities are required to have competitiveness, independence, sustainable reach, integrated information network, in order to maintain the quality of higher education. In fact, not all tertiary institutions have plenty of qualified resources to meet these demands. The emergence of changes in meso policy on higher education standards (SN Dikti) became a substantial influence for private tertiary institutions. Private tertiary institutions are urged to be able to adjust even beyond the standards of tertiary institutions that have been prepared by the central government. The external environment and any amendments to regulations for higher education meso policies may affect the choice of actions and institutional decisions in the operational process of higher education in terms of adapting with and adopting institutions. Exploration of sundry field findings of this study has revealed several aspects to view, it's how the regulations become a highly influential elements, organizational culture and work culture of other institutions, national, regional and global insights, the influence of inter-institutional cooperation, and assessment of international accreditation.

2020 FIA UB. All rights reserved.

\section{Introduction}

The highest level of national formal education is a higher education organized by a university which can transform people to have a qualified capability. In the institutional context, Private Universities step in to administer such higher education level, this kind of university is established and/ or organized by community. Any Private University needs breadth, specificity, and uniqueness of a balanced Tri Dharma Higher Education standard; harmonious and integrated in the context of enrichment; quality improvement; independence and competitiveness (Mattjik, 2018). Tasks and functions of the Private Universities as an institution, who act as the service providers, designers, and policy implementors and administrators (UNDP, 2011) are encouraged to meet their institutional capacity well.

The demand of qualifies universities is initiated by the idea of higher education quality assurance based on Law no. 20 of 2003, and in 2005 the Government Regulation Number 19 of 2005 was issued and was amended by the Government Regulation Number 32 of
2013 and, lastly was amended by the Government Regulation Number 13 of 2015 on the National Education Standards. Law No.12 of 2012 (Dikti Law), Government Regulation Number 8 of 2012 (KKNI), and the Regulation of the Minister of Research and Technology \& Higher Education No.44 / 2015 on Dikti National Standards. The regulation has resulted in changes in the operational procedures for higher education. The obvious normative domain also results in more detailed measures of the quality and resources of higher education.

The operation of higher education raises several problems such as the sift of 8 standards into 24 national standards. Nationally, University profiles of accreditation results of 8 SNPT criteria, namely 993 (22\%) accredited institutions, and 3,434 (78\%) institutions that have not been accredited, only 18,903 (76\%) accredited study programs, and 6,022 (24\%) not accredited (KEMENRISTEKDIKTI, 2016). This was also caused by the issue of 'World Class University' which resulted in unequal relations between corporations, countries, and universities; research institutions in this country with other countries and

\footnotetext{
* Corresponding author : Tel: +62818173679; e-mail: sofyan@binawan.ac.id
} 
universities; between foreign and domestic universities themselves (Subkhan, 2010).

The reliability of PTS institutional capacity depends on the degree of conformity, degree of fulfillment, and degree of exceedance of SN DIKTI, so as not to cause idle capacity (Aditya, 2014) of resources and to be carried out effectively and efficiently. Until now, the issue has become a general debate, especially on the existence of institutions and internal problems of tertiary institutions (Mones, 2016). If the existence of the institution was related to practice: falsification of diplomas, illegal university establishment, lecturer eligibility, minimum results of research, poor quality of curriculum, and results of graduates had no relevance to the needs of the community. The 2016 WEF report on the 11 Pillars of the Globe Competitiveness Index, Indonesia's competitiveness index in the East Asia and Pacific region is ranked 41 out of 138 countries (KEMENRISTEKDIKTI, 2016). The rating is under the countries of Switzerland, Singapore, Japan, Malaysia, Korea, and Thailand.

The results of the BAN-PT 2019 assessment and rating for 2017-2018 of 2,243 PTs have been accredited. Accredited A colleges are 95 universities, 881 universities are accredited B, and 1,267 universities are accredited C (BAN-PT, 2019). While the PTS accreditation profile in Indonesia shows, PTS A has 39 institutions, accreditation B has 683 institutions, and C accreditation has 930 institutions (BAN-PT, 2019). This illustrates that, there are Private Universities that have 1) ability to conduct resources improvement, 2) sufficient resources, but need to build capacity, and 3) unable to fulfill, it needs some endeavors to improve it, such as coaching, guidance and assistance with facilities.

These empirical issues, influenced by the system within the tertiary education environment, require universities to have sufficient capacity readiness to meet the changing times (Goodman et al, 1988), (Kagan \& Neuman, 1997), and (Weiner, 2009). Readiness as capacity is explained by (Brown, LaFond, \& Macintyre, 2001), or something that is owned (Mahembe, 2011) or intermediaries and resources (Dessing, 1960). Capacity is also defined as the ability to mobilize, balance and build (Grindle, 2002), the ability to vote (Grindle, 2000: 8 \& 20), or the ability to create (Grindle, Mason, \& Rockefeller, 2010), and as the ability to overcome problems (Grindle, 2007).

Many scholars explain institutional capacity, such as (Grindle \& Hilderbrand, 1995), (Brown, LaFond, \& Macintyre, 2001), (Fountain, 2001) (Bergström, 2005), (Matachi, 2006), (Boin \& Christensen, 2008), (He, 2008), (Purwaka, 2008), (Lee, 2012), (Moran, Rein, \& Goodin, 2015). While research on institutional capacity of tertiary institutions has been widely researched, by Popovici (2015), Bidel, Turek, \& Cichon (2015), Sendegeya \& Chiguvare (2016), Khoshbakht, Gou, \& Dupre (2018), and others. Their explanation leads to, institutional capacity is a resource of institutional performance as an initiation of effective, efficient, and sustainable development. Purwaka (2008) mentions if, institutional capacity can be seen as a potential, Brown, LaFord, \& Macintyre (2001) mention the system as capacity.

Popovici (2015) mentions, that there needs to be a balance between the government and public institutions for education that benefits the community, while Bidel, Turek, \& Cichon (2015) suggest that the administration of education has a multidimensional structure. In this connection, Moran, Rein, \& Goodin (2015) refer to it as what is possible, what can or cannot be done, while Sendegeya \& Chiguvare (2016) education development is a sustainable strategy. Actions on the influence of the environment as an institutional capacity of higher education have similarities with explanations of Purwaka's potential capacity (2008), (Brown, LaFond, \& Moacintyre, 2001), and Grindle \& Hilberbrand, 1995).

The strong shifting in operational regulations for tertiary education, as well as the demands for the application of very strict standards by the government, have urged the Private Universities to rebuild their capacities. Various efforts are needed to realize this. Because these changes require Private Universities to increase capacity, for its shortcomings (Potter \& Brough, 2004). Therefore, this analysis is carried out in the context of the 'actions environment' which influences the institution's actions in anticipating the influence of the Private Universities environment. This analysis is carried out by conducting explorations using explanatory analysis methods (explorations) to determine what effects, and actions taken by Private Universities in preparing the implementation of SN Dikti regulation. This research will be conducted at one of the Private Universities in DKI Jakarta that can reflect the focus of this research.

\section{Theory}

Capacity is interpreted in various meanings that are very close to the term development or building. At the very least, JICA calls it a fundamental difference, although in a process both strengthen one another (Matachi, 2006). However, the substance is in the unseen, and underestimated potential, because the locus of capacity exists in two different scopes, such as endogenous and exogenous, or inter-institutional (inclusive) and intra-institutional (exclusive) (Lee, 2012) and (He, 2008). Many terms to interpret the word capacity is not just a literal definition, such as (Grindle, 2002); (Grindle, 2007); (Brown, LaFond, \& Moacintyre, 2001); and (Knopfel et al., 2007) who called it ability.

Capacity also means intermediaries and resources (Dessing, 1960) and (Atkinson \& Willis, 2006); or competencies/what they have (Mahembe, 2011) which is not much different from the explanation of design in the clause of institutional resources. Capacity is productivity (the productive capacity) (Grindle, Mason, \& Rockefeller, 2010), which means the ability to create. Their perspective on the initial mechanism of policy and socio-economic development, the effectiveness of actions as a development medium that requires the 
ability to create to translate development, although some actions show low results, especially on institutional and individual actions. Grindle (2007) quotes the statement of Hewitt de Alcántara which states, '... Not surprisingly, advocating good governance raises a host of questions ...'. However, it is not denied, capacity can have an internal coherence value in the selection of strategies that are influenced by time, conditions, ongoing political support, institutional bureaucracy that is able to take on tasks effectively, as well as learning and experience.

Perhaps, the explanation of North (1993) can be taken, namely "The kinds of skills and knowledge of individuals and their organizations acquiring will shape evolving perceptions about opportunities and hence choices that will incrementally alter institutions". Institutions have interdependence with capacities that contain opportunities and choices that can change an institution. The details of these influences change the institutional approach which not only means an organized institution, but almost all possible environmental, legal, and customary, incentive, motivational, or organizational culture, or other aspects (Matachi, 2006), are broader than that (Milen, 2001). Even Knopfel et al. (2007) stated if the institution becomes a place for the administrators and implementor as well.

There are reciprocal interactions between institutions, organizations, and individuals (human resources), related to the consideration of feedback from their actions that are not always efficient and vice versa, sometimes can change actions, even though institutionalized behavior is difficult to change, and results are not always positive (Carter, 2014). Institutionalization is not only a reciprocal interaction, but an institution is also a choice of strategy, an effort to change the composition of defense / opposition and change the balance by favoring change (Grindle, 2002). Changes in institutional can be actions behind the persistence of sustainable relations between institutions and policies (Harper, Jones, \& Watson, 2012: 20), or not only as a functional response to demands for efficiency, but effectively adopt whatever is perceived by the institutional environment as an appropriate and legal, although not efficient in handling public affairs. The new institutional view sees that, institutional action is organized, and it is decided to use trade-offs between problem content and uncertainty that can be faced in real time (Thoenig, 2011). He also mentioned if the institutional can be derived in the meso or micro context which reverses the macro interpretation which creates dependency on the institutional level, but the actions in it have empirical compatibility, and are still limited by government rules.

The environment greatly influences actions, which reflect readiness to face all possibilities. Interventions may occur to increase capacity, dynamic processes that encourage individuals or institutions to adapt and develop according to all their potential (Vita, Fleming, $\&$ Twombly, 2001). The environment consists of many aspects, such as national and regional regulations, institutional management policies, inter-institutional relations, interactions and dependencies between one and the other (Imbaruddin, 2003). The environment of influence can also be anything that affects the scope of institutional outreach, access (mobility space) in the long run, or something that influences the approach used by institutions in carrying out institutional capacity building (Brown, LaFond, \& Moacintyre, 2001).

The stronger the capacity, the stronger the potential arises, because it is a determinant of the success of an activity (action), also to be sustainable (Pattillo, McCarthy, \& Molinari, 2010). However, this also indicates a lack of public sector capacity (Potter \& Brough, 2004), which requires action and decision making at the micro level. Grindle \& Hilberbrand (1995) explain, the action environment is a dimension that refers to social, political, and economic conditions, where public sector institutions carry out their activities, and stability and conflict can facilitate or hinder the actions of these institutions. The explanation is too broad (macro), but sufficient to explain the meaning of the action environment in a particular context, with a more specific scope.

The explanation concerns the execution of national (macro) policies, and effective policy execution, otherwise the available resources will be wasted, and many opportunities will be lost, and capacity can be reduced in the future (Gafar, 2016). This concerns the influence of the institutional environment that is broader than the institution itself, such as rules, procedures established by the government, informal structures of influence on the functions of the public sector that limit or vice versa (Milen, 2001), or the development of change, social conflict, class structure, other civic organizations, and society (Grindle \& Hilberbrand, 1995). Environmental influences cannot be generalized, especially in the context and conditions of the environment (Thoenig, 2011). The effectiveness and efficiency of actions taken, sometimes in contradiction (Harper, Jones, \& Watson, 2012: 20). It seems that institutions must choose between effective or efficient actions, to avoid the uncertainty of decisions at the same time in the context of influence (Thoenig, 2011). Actions as decisions taken by institutions differ on the functions and objectives taken, the abilities used to plan and implement policies (Fukuyama, 2004). Fukuyama also emphasized that the ability (capability) to act is often used by not distinguishing between strength and capacity.

This is becoming vague, on the understanding of the environmental action that causes an institution to exist, be able to stand up and function (Purwaka, 2008). This was explained by Grindle relies on the context of the existence of institutions and good performance despite being in an unfavorable environment and overall poor public sector performance (Grindle, 1997). This vagueness of understanding also arises from the explanation of Kaplan (2001) which mentions an institution that does not understand its actions or work, or in any other words, having no sufficient capacity. This does not become a vague meaning of the action environment. Still, the environment and actions 
become one term that means the environment that influences the institution, as well as the actions taken or taken by the institution to carry out or anticipate that influence.

\section{Research Method}

The analysis on the Private University's actions environment upon the implementation of the SN Dikti regulation uses a qualitative approach, with an exploratory (exploration) method. Therefore, the results of this study are a new preposition or a new model which in turn can determine the direction of generalization of a social phenomenon (Mudjiyanto, 2018). As one of the post-positivistic analysis approaches, this research is more directed at interpreting or expressing meaning naturally (Gabrielian, Yang, \& Spice, 2008).

This research will be conducted at one of the Private Universities in DKI Jakarta, as a reflection of universities. While the focus of research rests on the disclosure of the 'what' environmental aspects of the actions affecting and 'what' actions are prepared to implement the SN Dikti policy. The data collected has several forms, such as interviews and field observations. The results of the data are then combined with the systematization of exploration disclosures which are ultimately presented as field data and analyzed to bring about generalizations about the PTS actions environment.

\section{Results}

The change of SN Dikti's policy from 8 standards to 24 standards, as well as exceeding that must be had by PTS requires private institutions of higher education to take some adjustments and anticipation. Either directly or indirectly, this policy change has a strong influence on the existence and suitability of PTS capacity. In addition to higher education standards, administrative procedures, criteria and instruments for assessing higher education accreditation have a very strong influence on the environment and the readiness of institutions to carry out higher education. Administrative procedures are also equipped with integrated systems, namely Fedder, Sister lecturers, and EWS universities, as an integrated reporting system with the national Higher Education Database. Other regulations that apply nationally also influence the implementation of PTS higher education. These rules and policies can affect the value of PTS, as well as the mainstreaming of public opinion on a positive image.

Aspects of the influence environment also gave rise to the influence of governance of other institutions which were later adopted into Private University governance mechanisms. This is caused by the success of the institution in carrying out its management, as well as the assumption of the authorities to the success can be done by Private University. However, this adoption needs to be adjusted again, considering the large number of institutions that collaborate with this Private Universities, such as other universities, corporations (Business and industrial world), and government institutions. This collaboration occurs because there are demands and the inability of institutions to provide educational practice places. This adjustment is also caused by differences in organizational culture that has been institutionalized. This adoption also requires an analysis of conditions that require adjustment time by sorting out, which principles or practices can and cannot be imitated into the Private Universities governance system.

Private University considers the principle or practice of the institution as a role model and can be a brand mark in the process of developing its institutional capacity. Other influences are national insights, such as basic philosophy, folkways, and eastern culture inherent in Indonesian society in general, regional issues concerning labor competencies and opportunities for opening regional accessibility. Global issues regarding the assessment and ranking of World Class University by THESGS and Webometric that reflect the health level of tertiary institutions. The quality of university is also influenced by the results of the audit to its financial condition which show a positive image of the financial condition of institutions which can increase the trust of other institutions or the public for PTS.

The influence of the environment leads to two important aspects that reflect the existence of PTS, namely recognition or legitimacy and a positive image (public value of publicity) of the institution. In principle, this existence is determined by the act of maintaining the legitimacy and trust that has been owned by PTS to be able to continue to carry out higher education. These actions include strategic, tactical and technical actions. Certainly, strategic action is required to set a vision which tend to be carried out by agreeing and complying with the policy changes of SN Dikti, adjusting the content and context of the Higher Education Statute, preparing a Strategic Plan (Renstra). This strategic action was carried out by 1) reaffirming the commitment of the leaders of PTS internal institutions, 2) expanding Tri Dharma Higher Education service efforts in the national, regional, and international scope, 3 ) increasing the capacity of human resources, especially the capacity and capability of lecturers, and 4) revenue optimization aside from students.

The PTS tactical actions in preparing its institutional capacity are 1) increasing the standard of higher education as a distinctive feature of the institution, 2) reforming and adjusting the university governance system, 3) guaranteeing the quality of education and institutional implementation with the Internal Quality Assurance System (SPMI), 4) integration of administrative systems and internal reporting systems with the higher education network system owned by the Ministry of Research and Technology, 5) increasing the number and quality of research and community service practices, and 6) optimizing the utilization of institutional resources.

This technical action in adjustment that reflects the readiness of the application of SN Dikti by PTS is realized by several activities, namely: 1) the application 
of SPMI into every institutional practice, especially at the level of Higher Education (Rectorate), Faculty, and Departments, 2) ensuring quality assurance by analyzing and measuring performance in a structured and systematic manner, 3) capturing and expanding the reach of institutional cooperation, both national, regional and international, bound by MoUs and MoAs, 4) submitting reporting and filling PTS data regularly in accordance with the updating of institutional data through the system integrated Feeder, Sister, EWS, and database of the Ministry of Research and Technology (PD Dikti), 5) conduct research and community service periodically with the renewal of useful knowledge, and 6 ) utilization of institutional resources that have idle capacity as a source of income another institution.

\section{Discussion and conclusion}

SN Dikti's policies are meso policies based on Law No.20 / 2003 and Law No.12 / 2012. The issuance of these policies gave birth to various micro policies in the form of regulations governing systematic, procedures and assessing Private Universities capacity in carrying out SN Dikti's policies. The implementation of the SN Dikti policy is a mandate that must be carried out by PTS, as a legitimate and formal education institution. Private Universities cannot be separated from formal implementation responsibilities that must be reported to the Ministry of Research and Technology and other government institutions, as well as informal responsibilities to the society. For this reason, Private Universities prepare its capacity to be able to implement SN Dikti's policies within its own tertiary institution.

Private Universities preparation is an institutional action undertaken by internal authority and Private Universities institutions. This preparation is done by uniting development and building practices in one place. Although they are different, PTS converges these two actions as a mutually reinforcing process (Matachi, 2006). This view slightly shifts the viewpoint of exogenous and endogenous capacities that are difficult to put together (He, 2008, \& Lee, 2012), but the actions of PTS in preparing capacity place these differences in one pattern of the adjustment process. PTS chose to be ready to implement or adjust SN Dikti's policy, because institutions have sufficient capacity, Private Universities have the potential that gives birth to an action (Goodman, et al., 1998) strategic, tactical, as well as technical. For Private Universities that has sufficient capacity, this becomes strength and belief, that institutions only need to adjust. Conversely, for Private Universities that have limited capacity, this is a challenge to the readiness and existence of institutions in the tertiary education environment.

The convergence of Private Universities capacity processes indicates that the readiness for implementation, both definition and construction, is not in a narrow space (Kagan \& Neuman, 1997). This concerns who is affected and who influences, accountability, and the procedures for implementing the SN Dikti policy. The composition of the convergence action process undertaken by Private
Universities is a multi-level and multi-aspect construction. Because PTS is a collective institution, and actions in the effort to implement SN Dikti's policies have resulted in some changes in capacity structures both complex structures and functions (Weiner, 2009). This requires the commitment of all institutional internal authority stakeholders, on the basis of a collective motive and an emphasis on the same determination. Implementation is prepared in such a way, involving all organs and internal units which are then institutionalized in the form of internal quality policies, quality manuals, quality standards, and quality procedures. This mainstreaming requires control and connectivity of internal governance, supervision, and reporting (formal or informal). Fedder, Sister, EWS and PD Dikti act as external controls, while SPMI acts as an internal control for the tertiary education of Private Universities. In the end it leads to the sustainability of tertiary education in PTS.

The actions of institutions or authorities reflect Private Universities readiness to implement SN Dikti's policies. Such a dynamic process in the convergence of development or capacity building encourages institutions or individuals to be able to adapt to the environment in accordance with the potential possessed by Private Universities. Although the practice of standardization of higher education emphasizes the same capacity and at the same time requires characteristic characteristics as a distinguishing capacity. The condition and situation of Private Universities internal environment cannot be synchronized with other institutions, even though it has the same institutional form. Such characteristics of potential institutional capacity must be realized or fulfilled. The form is a set of quality capabilities that enable Private Universities environment system performance to be able to survive and integrate effectively and efficiently within the boundaries of an external institutional system that is binding.

Potential includes some impetus for the impossibility and limitations of long-term access in preparing the institutional capacity of its internal environment. It is not impossible if this action has visionary affordability. The action strategy needs to be carefully crafted, considering all kinds of environmental influences that directly or indirectly affect each stage of preparation, as well as at the time of application. Dynamism is in tactical and technical measures, which involve the accuracy of SN Dikti's policy execution to the lowest level of Private Universities institutions. Because, if the execution as a choice of action is not right, then the preparation and utilization of Private Universities resources will be in vain (or idle) (Gafar, 2016). This also affects the surrounding environment which initially influences the Private Universities internal environment. Such conditions, sometimes contradictory, especially in the hope of questioning the effectiveness or efficiency of actions in a process of preparing the capacity of institutions to implement the SN Dikti policy.

Even though the institution becomes the place of preparation as well as the implementor (executor) 
(Knopfel, Larrue, Varone, \& Hill, 2007: 255-256), it is possible that it will lead to failure, or vice versa. Therefore, institutional action is not always focused on centered decision choices. Reciprocal interaction between institutions, internal institutions, and stakeholders must be dynamically established to form an opportunity. This is what is illustrated by the action environment which can ultimately change the conditions of institutional readiness. Conversely, at one time can change the environment of influence with a broader scope, namely higher education institutions themselves. So, it is important to remember, that actions within the institution, collectively, are investments that have a long-term impact, and are capable of producing efficiencies, although at first, they are not visible. Even the prepared internal environmental actions do not show any improvement or potential that results in performance effectiveness. This is also what Grindle (2002) said as an effort to change the composition of the persistence/ resistance, changing the balance by favoring change.

Strategic, tactical, or even technical choices are a form of the persistence of PTS in showing interdependence (North, 1993) between action and the environment, which is not only structured, but functionally becomes a response to the demands for efficiency and effectiveness of the SN Dikti policy implementation process. Connectivity between the environment and Private Universities institutional actions becomes one thing that cannot be denied as an institutional capacity, especially in the dynamic interrelationship of the process. Action as an institutional capacity then embodies the legitimacy and legitimacy of adaptation or the adjustment of institutional resources to the method or standardization, or to environmental demands in a more dynamic, more organized manner, with real-time decision making.

Exploration or exploration of Private Universities capacity, especially the action environment contains many aspects of influence, as well as institutional actions. The action environment within the institution is the capacity of Private Universities institutions. Collectively, the act of forming internal environmental conditions is an investment that has a long-term impact and is able to produce efficiency and effectiveness of Private Universities institutional choices. Reciprocal interaction between institutions, internal institutions, and stakeholders in strategic, tactical, and technical actions must be dynamically intertwined to form an opportunity. This illustrates the potential for an action environment that can ultimately change the readiness of institutions to implement the SN Dikti policy. The accuracy of execution to the lowest level of Private Universities, is also important, so that the resources that have been prepared are not in vain (idle).

\section{References}

Aditya, M. (2014). Perhitungan Idle Capacity Dengan Menggunakan CAM - I Capacity Model Dalam
Rangka Efisiensi Biaya Pada PT X. Esensi

Jurnal Bisnis dan Manajemen, 4(2) 140-155.

Atkinson, R., \& Willis, P. (2006). Community Capacity Building - A Practical Guide. School of Sociology and Social Work University of Tasmania.

Buckley, J., \& Casson, M. (1989). A theory of cooperation in international business. The multinational enterprise. Palgrave Macmillan.

BAN-PT. (2019). Distibusi Pemeringkatan: Badan Akreditasi Nasional Perguruan Tinggi. BAN PT.

Bergström, L. (2005). Development of Institutions is Created from the Inside: Sweden: SIDA.

Bidel, D., Turek, I., \& Cichon, S. (2015). Multidimensional Management of a Higher Education Institution. International Journal of Arts \& Sciences, 08 (02), 199-213.

Boin, A., \& Christensen, T. (2008). The Development of Public Institutions: Reconsidering the Role of Leadership. Administration \& Society, 40(3) 271-297.

Brown, L., LaFond, A., \& Macintyre, K. (2001). Measuring Capacity Building. Chapel Hill.

Carter, B. (2014). Inclusive Institutions: Topic Guide. Birmingham, GSDRC University of Birmingham.

Dessing, M. (1960). Support for Microenterprises: Lesson for Sub-Sahara Africa. Library of Congress Cataloging-in-Publication Data Harvard Institute for International Development at Harvard University.

Fountain, E. (2001). Building the Virtual State: Information Technology and Institutional Change. Brookings Institution Press.

Fukuyama, F. (2004). The Imperative State - Building. Journal of Democracy, 3(1)17-31.

Gabrielian, V., Yang, K., \& Spice, S. (2008). Chapter 10: Qualitative Research Methods. In G. J. Miller, \& K. Yang, Handbook of Research Methods in Public Administration. Taylor \& Francis Group.

Goodman, M., Speers, A., McLeroy, K., Fawcett, S., Kegler, M., Parker, E. (1998). Identifying and Defining the Dimensions of Community Capacity to Provide a Basis for Measurement. Health Education \& Behavior. 25 (3), 258-278.

Grindle, S. (1997). Divergent Cultures? When Public Organizations Perform Well in Developing Countries. World Development, 1(1) 481-495.

Grindle, S. (2000). Designing Reforms: Problems, Solutions, and Politics. John F. Kennedy School of Government Harvard University.

Grindle, S. (2002). Interests, Institutions, and Reformers: The Politics of Education Decentralization in Mexico. Cambridge: 
Kennedy School of Government Harvard University.

Grindle, S. (2007). Good Enough Governance Revisited. Development Policy Review, 25 (5), 553-574.

Grindle, S., \& Hilderbrand, E. (1995). Building sustainable capacity in the public sector: What can be done? Public Administration and Development, 1(1) 441-469.

Grindle, M. S., Mason, E. S., \& Rockefeller, D. (2010). Social Policy in Development: Coherence and Cooperation in The Real World. Harvard Kennedy School.

Harper, C., Jones, N., \& Watson, C. (2012). Gender justice for adolescent girls: tackling social institutions. Towards a conceptual framework. ODI.

He, K. (2008). Institutional Balancing and International Relations Theory: Economic Interdependence and Balance of Power Strategies in Southeast Asia. European Journal of International Relations, 1(1) 489-518.

Imbaruddin, A. (2003). Understanding Institutional Capacity of Local Government Agencies in Indonesia. Canberra: The Australian National University.

Kagan, L., \& Neuman, J. (1997). Defining and implementing school readiness: Challenges for families, early care and education, and schools. Sage Publications, Inc.

Kaplan, A. (2001). Capacity Building: Shifting the Paradigms of Practice. In D. Eade, \& E. Legteringen, Debating Development NGOs and The Future. Oxfam GB for Oxfam International.

KEMENRISTEK. (2016). Kebijakan Kemenristek Dalam Mewujudkan PTS Bermutu Melalui Akreditasi Institusi. Kementerian Riset, Teknologi, dan Pendidikan Tinggi. Kementerian Riset, Teknologi, dan Pendidikan Tinggi RI.

Khoshbakht, M., Gou, Z., \& Dupre, K. (2018). Energy Use Characteristics and Benchmarking for Higher Education Buildings. Energy \& Buildings, 164(2), 61-76.

Knopfel, P., Larrue, C., Varone, F., \& Hill, M. (2007). Public Policy analysis. First Published in Great Britain.

Lee, S. (2012). The Evolutionary Dynamics of Institutional Balancing in East Asia. EAI Asia Security Initiative Working Paper, 1-32.

Mahembe, E. (2011). Literature Review on Small and Medium Enterprises' Access to Credit and Support in Sounth Africa. Underhill Corporate Solutions (UCS).
Matachi, A. (2006). Capacity Builidng Framework: UNESCO - IICB. Addis Ababa, Uthopia: United Nations Economic Commission for Africa.

Milen, A. (2001). What do we know about capacity building? An overview of existing knowledge and good practice. Department of Health Service Provision-World Health Organization.

Mones, A. Y. (2016). Pendidikan Tinggi Di Indonesia: Status, Isu dan Prospek. Jurnal Sosioteknologi, 24(10) 1-6.

Moran, M., Rein, M., \& Goodin, R. E. (2015). Handbook Kebijakan Publik. Nusa Media.

Mudjiyanto, B. (2018). Tipe Penelitian Eksplorasi Komunikasi (Exploratory Reseach in Communication Study). Jurnal Studi Komunikasi dan Media, 1(2)65-74.

North, D. C. (1993). Institutions and credible commitment. Journal of Institutional and Theoretical Economics, 1(2)11-23.

Pattillo, E., McCarthy, D., \& Molinari, D. (2010). Capacity Building for Simulation Sustainability. Clinical Simulation in Nursing, 1(1) 185-191.

Popovici, E. (2015). Institutional Governance From The Perspstive of Superior Education in The Republic of Ecuador. Review of The Air Force Academy, 1 (28), 171-176.

Potter, C., \& Brough, R. (2004). Systemic capacity building: a hierarchy of needs. Health policy and planning, 19(5), 336-345.

Purwaka, H. (2008). Model Analisis Pengembangan Kapasitas Kelembagaan. Fakultas Hukum Unika Atma Jaya.

Sendegeya, M., \& Chiguvare, Z. (2016). The Role of Academia in Capacty Building for Sustainable Energy Development: The Case of Namibia. Enegery Procedia, 93(1), 218-222.

Subkhan, E. (2010). Mempertanyakan Orientasi World Class University. Seminar Nasional BEM FE UNSOED. Unsoed.

Thoenig, C. (2011). Institutional Theories and Public Institutions.: New Agendas and Appropriateness. In P. B. J.Pierre, The Handbook of Public Administration. Sage Publications Ltd.

UNDP. (2011). Governance Principles, Institutional Capacity and Quality. UNDP 10017 USA.

Vita, J., Fleming, C., \& Twombly, E. C. (2001). Building Nonprofit Capacity: A Framework for Addressing the Problem. In C. J. Vita, \& C. Fleming, Building Capacity in Nonprofit Organizations. The Urban Institute.

Weiner, J. (2009). A theory of organizational readiness for change. Implementation Science, 4 (1)671679. 